\title{
Ekstrakurikuler Seni Tari dalam Membentuk Nilai Karakter Bersahabat
}

\author{
Nawang Wulan ${ }^{1}$, Husni Wakhyudin ${ }^{2}$, Intan Rahmawati ${ }^{3}$ \\ 1,2,3 Jurusan PGSD FIP UPGRIS, Kota Semarang Indonesia \\ e-mail: nawangwulan368@gmail.com
}

\begin{abstract}
Abstrak
Penelitian ini bertujuan untuk mengetahui bagaimana cara membentuk nilai karakter bersahabat melalui kegiatan ekstrakurikuler seni tari di SDN Tlogomulyo Semarang. Proses penelitian yang digunakan adalah deskriptif naratif dengan menggunakan analisis deskriptif. Tujuan penelitian ini adalah untuk mengetahui bagaimana cara membentuk nilai karakter bersahabat melalui kegiatan ekstrakurikuler seni tari SDN Tlogomulyo Semarang. Subyek dalam penelitian ini adalah semua siswa yang ikut kegiatan ekstrakurikuler seni tari dan guru pelatih seni tari. Hasil dalam penelitian ini adalah peran aktif kegiatan ekstrakurikuler seni tari dalam membentuk nilai karakter bersahabat siswa sudah terbentuk dengan baik. Hal tersebut direalisasikan ketika anak dalam menari bisa membantu temannya ketika ada teman yang belum bisa menari, anak mengenal semua temannya dalam menari dan anak tidak membeda bedakan teman dalam menari.
\end{abstract}

Kata Kunci : Ekstrakurikuler Seni Tari, Karakter Bersahabat

\begin{abstract}
This research aims to find out how to form a friendly character value through dance extracurricular activities at Tlogomulyo Elementary School Semarang. The research process used was descriptive narrative using descriptive analysis. The purpose of this study was to find out how to shape the value of friendly characters through extracurricular dance activities at SDN Tlogomulyo Semarang. The subjects in this study were all students who took part in dance extracurricular activities and dance coaches. The results of this study are the active role of dance extracurricular activities in shaping the value of students' friendly character that has been well formed. This is realized when children in dancing can help their friends when there are friends who have not been able to dance, children know all their friends in dancing and children do not differentiate between friends in dancing.
\end{abstract}

Keywords: Extracurricular Dance, Friendly Characters 


\section{Pendahuluan}

Pendidikan lebih dari sekedar pengajaran, yang dapat dikatakan sebagai suatu proses transfer ilmu, transformasi nilai, dan pembentukan kepribadian dengan segala aspek yang dicakupnya. Dengan demikian pengajaran lebih berorientasi pada pembentukan spesialis atau bidangbidang tertentu, oleh karena itu perhatian dan minatnya lebih bersifat teknis. Pendidikan merupakan suatu proses yang diperlukan untuk mendapatkan keseimbangan dan kesempurnaan dalam perkembangan individu maupun masyarakat. Penekanan pendidikan dibanding dengan pengajaran terletak pada pembentukan kesadaran dan kepribadian individu atau masyarakat di samping transfer ilmu dan keahlian. Dengan proses semacam ini suatu bangsa atau negara dapat mewariskan nilai-nilai keagamaan, kebudayaan, pemikiran dan keahlian kepada generasi berikutnya, sehingga mereka betul-betul siap menyongsong masa depan kehidupan bangsa dan negara yang lebih cerah (Nurkholis ,2013).

Pendidikan yang berbasis karakter dan budaya bangsa adalah pendidikan yang menerapkan prinsip-prinsip dan metodologi ke arah pembentukan karakter anak bangsa pada peserta didiknya melalui kurikulum terintegrasi yang dikembangkan di sekolah. Kerangka pengembangan karakter dan budaya bangsa melalui pembelajaran di kalangan tenaga pendidik dirasakan sangat penting. Sebagai agen perubahan, pendidik diharapkan mampu menanamkan ciri-ciri, sifat, dan watak serta jiwa mandiri, tanggung jawab, dan cakap dalam kehidupan kepada peserta didiknya. Di samping itu, karakter tersebut juga sangat diperlukan bagi seorang pendidik karena melalui jiwa ini, para pendidik akan memiliki orientasi kerja yang lebih efisien, kreatif, inovatif, produktif serta mandiri (Suyito ,2017).

Dasar budaya lokal dan nilai-nilai ke-Nusantaraannya yang telah ditumbuhkan dari jenjang usia sekolah (SD) diharapkan membentuk nilai-nilai pribadi yang meliputi (a) menunjukan pemahaman positif tentang diri dan percaya diri. Ini hasil dari pembentukan pribadi yang positif. Semua penampilan tari etnik di Indonesia menunjukan pola kepribadian yang positif, yaitu kegagahan, keperkasaan, kelembutan, atau kesetiaan; (b) menunjukan kemampuan untuk berinteraksi dengan orang lain dan alam sekitar. Ini hasil dari pem-bentukan nilai-nilai sosial untuk menyadari tentang kehidupan itu adalah proses. Jenis tari etnik daerah di Indonesia menunjukan sebuah proses untuk mencapai sebuah kebenaran, yaitu tentang kejahatan akan berakhir dengan kekala-han, kebaikan akan mencapai pada keluhuran; (c) menunjukan berpikir runtut. Ini menunjukan pada nilai tentang proses menuju hasil yang dicapai. Tari etnik di Indonesia mempunyai dasar konsep-tual. Ada nilai-nilai pikiran, logika, dan rasiona-litas; (d) berkomunikasi secara efektif, ini menun-jukan bahwa intelektualitas memilih dan memilah adalah potensi manusia yang mampu mencapai tingkat kualitas hidup. Tari etnik di Indonesia pada dasarnya mempunyai potensi sebagai media komunikasi, tidak hanya komunikai antar manusia, namun juga sebagai media komunikasi dengan roh dan alam semesta; (5) terbiasa hidup sehat, ini adalah nilai yang mengarah pada penghargaan tentang hidup, sehingga hidup itu adalah memiliki arti penting. Tari etnik di Indonesia menujukan dasar pembentukan dan pemeliharaan tubuh, sehingga mampu memper-tahankan kecantikan, keperkasaan, dan ketang-kasan; (e) menunjukan kematangan fisik. Ini adalah nilai yang menghargai tentang fungsi tubuh/badan sebagai media untuk mencapai tingkat keterampilan. Bahwa hidup ini akan dihadapakan pada sejumlah pekerjaan. Semua jenis tari di Indonesia diperoleh dari hasil kedisiplinan dan kerja keras, karena di dalamnya memiliki konsep tentang nilai estetik yang tinggi (Sustiawati ,2017).

Ekstrakurikuler merupakan kegiatan pendidikan diluar jam pelajaran yang ditunjukkan untuk membantu perkembangan siswa ,sesuai kebutuhan ,potensi ,bakat dan minat mereka melalui kegiatan yang secara khusus diselenggarakan oleh peserta didik dan tenaga kependidikan yang berkemampuan dan berkewenangan di sekolah Wijayani (2013: 108) dalam Jurnal. Selain pendidikan formal yang guru berikan, siswa juga perlu pendidikan non formal diluar jam pembelajaran, misalnya dengan siswa harus mengikuti ektrakulikuler yang ada di sekolah.

Ekstrakurikuler menurut Permendiknas No. 39 tahun 2018 tentang pembinaan kesiswaan kegiatan ekstrakurikuler merupakan salah satu jalur pembinaan kesiswaan. Kegiatan yang diikuti dan dilaksanakan siswa baik disekolah maupun di luar sekolah. Kegiatan ekstrakurikuler adalah kegiatan yang digunakan untuk mengasah bakat yang dimiliki oleh peserta didik. Salah satu ekstrakurikuler untuk mengasah bakat peserta didik yaitu seni tari.

Ekstrakurikuler seni tari itu sendiri adalah salah satu cabang seni yang merupakan kesenian yang sekarang sudah banyak diajarkan diberbagai sekolah dasar. Proses pembelajaran tari adalah suatu interaksi antar siswa dengan guru dalam rangkaian kegiatan 
penyampaian materi yang bertujuan menciptakan perubahan tingkah laku dalam berkesenian dengan budaya untuk mewujudkan hasil belajar yang maksimal (Putri 2014:4) dalam jurnal . Dengan adanya ekstrakurikuler seni tari di SD digunakan untuk mengasah bakat minat yang dimilik siswa dan untuk menumbuhkan nilai karakter yang baik pada siswa untuk bekal masa depannya.

Kegiatan ekstrakurikuler merupakan wahana dalam mengembangkan bakat dan minat siswa diluar jam pelajaran. Ekstrakurikuler menurut Asmani (2011: 62) adalah kegiatan pendidikan diluar jam mata pelajaran dan pelayan konseling untuk membantu pengembangan peserta didik sesuai dengan kebutuhan, potensi, bakat, dan minat mereka melalui kegiatan yang secara khusus diselenggarakan oleh pendidik dan atau tenaga kependidikan yang berkemampuan dan berwenang di sekolah. Noor (2011: 32) mengemukakan setelah kegiatan ekstrakurikuler diselenggarakan sejak lama di sekolah, mulai dari sekolah dasar sampai dengan perguruan tinggi dampaknya belum signifikan bagi pengembangan keterampilan peserta didik, hal tersebut disebabkan dalam pengelolaan kegiatan ekstrakurikuler di sekolah belum maksimal dan hanya cenderung mendorong pengembangan bakat dan minat peserta didik. Menurut Asmani (2011:63) kegiatan ekstrakurikuler selama ini dipandang sebelah mata, hanya sebagai pelengkap kegiatan intrakurikuler. Hal itu sangat disayangkan sekali, karena menurut Karim (2013: 2) melalui ekstrakurikuler siswa diarahkan memiliki karakter yang abadi dan universal seperti kejujuran, kedisiplinan, menghargai pluralisme, mempunyai empati dan simpati. Semua aspek ini akan sangat menunjang kesuksesan peserta didik kelak di masa mendatang (Yuni ,2016).

Muslich $(2011 ; 1)$ mengemukakan bahwa Dampak globalisasi yang terjadi saat ini membawa masyarakat Indonesia melupakan pendidikan karakter bangsa. Padahal pendidikan karakter merupakan suatu pondasi bangsa yang sangat penting dan perlu ditanamkan sejak dini kepada anak - anak. Dalam dunia pendidikan, seperti siswa dengan teman sebayanya kurang adanya rasa sosialisasi, kurangnya rasa toleransi terhadap teman, mulai menghilangkan sikap simpati terhadap keluarga dan teman sebaya yang merupakan salah satu budaya bangsa Indonesia .Hal tersebut tidak hanya merugikan siswa namun juga dapat merugikan pihak sekolah dalam mencapai tujuan .Ini karena disebabkan kurang adanya kerjasama dengan siswa untuk mencapai tujuan yang diinginkan sekolah .Mengenai hal tersebut terhadapat penurunan moral dan etika yang terjadi, maka pendidikan karakter menjadi hal yang sangat diperlukan oleh siswa .

Nilai karakter tersebut jika diterapkan dengan baik dan benar maka akan membawa manfaat yang baik bagi kehidupannya kelak. Namun pada dasarnya hal itu berbeda dengan kenyataan saat ini terutama dalam pendidikan, siswa memiliki karakter yang kurang baik Siswa lebih mengisi waktu luangnya untuk hal yang merugikan dirinya sendiri ,hal ini berarti siswa kurang memanfaatkan waktu luangnya untuk hal yang bermanfaat bagi kehidupannya .

Listyarti (2012: 5-8) mengemukakan bahwa mulai tahun 2011, seluruh tingkat pendidikan di Indonesia harus menyisipkan pendidikan berkarakter . ada 18 nilai karakter, yaitu 1.Religius 2.Jujur 3.Toleransi 4.Disiplin 5.Kerja keras 6.Kreatif 7.Mandiri 8.Demokratis 9.Rasa Ingin Tahu 10.Semangat Kebangsaan 11. Cinta Tanah Air 12.Menghargai Prestasi 13.Bersahabat / Komunukatif 14.Cinta Damai 15.Gemar Membaca 16.Peduli Lingkungan 17.Peduli Sosial 18.Tanggung Jawab. Nilai karakter tersebut sangat penting bagi pribadi seseorang terutama siswa, karena siswa merupakan penerus bangsa yang sebaiknya tidak hanya perlu pendidikan akademik namun juga perlu kepribadian yang baik dengan melalui pendidikan karakter untuk bekal masa depannya .

Menurut buku Pedoman Pelaksanaan Pendidikan Karakter oleh Kementrian Pendidikan Nasional bahwa strategi pelaksaan pendidikan karakter di sekolah ada 4 cara yaitu : 1)Mengintegrasikan kesetiap mata pelajaran, 2)Pengembangan budaya sekolah, 3)Melalui kegiatan ekstrakurikuler, 4)Kegiatan keseharian dirumah .

Secara terminologi, menurut Alwisol (2006:8) mengartikan karakter sebagai gambaran tingkah laku yang menonjolkan nilai benar-salah, baik-buruk, baik secara eksplisit maupun impilisit. Terkait dengan ini, Wynne (1991:45) mengatakan kata karakter berasal dari bahasa Yunani yang berarti "to mark" (menandai) dan menfokuskan pada bagaimana mengaplikasikan nilai kebaikan dalam bentuk tindakan atau tingkah laku. Oleh sebab itu seseorang yang berperilaku tidak jujur, kejam, atau rakus dikatakan sebagai orang yang berkarakter jelek, sementara orang yang berperilaku jujur, suka menolong dikatakan sebagai orang yang berkarakter mulia. Jadi istilah karakter erat kaitannya dengan personality (kepribadian) seseorang, di mana seseorang bisa disebut orang yang berkarakter (a person of character) jika tingkah lakunya sesuai dengan kaidah moral yang berlaku. Karakter mengacu pada 
serangkaian sikap (attitudes) dan perilaku (behaviors). Karakter meliputi sikap seperti keinginan untuk melakukan hal yang terbaik, kapasitas intelektual seperti berfikir kritis dan alasan moral, perilaku seperti jujur dan bertanggung jawab, mempertahankan prinsip-prinsip moral dalam situasi penuh keadilan, kecakapan interpersonal dan emosional yang memungkinkan seseorang berinteraksi secara efektif dalam berbagai keadaan, dan komitmen untuk berkontribusi dengan komunitas dan masyarakatnya. Karakteristik adalah realisasi perkembangan positif sebagai individu (intelektual, sosial, emosional, dan etika). (Assidiqi ,2015).

Sudewo (dalam Nashir, 2013:10), menyatakan bahwa karakter artinya perilaku yang baik, yang membedakannya dari "tabiat" yang dimaknai perilaku yang buruk. Karakter merupakan "kumpulan dari tingkah laku baik dari seorang anak manusia, tingkah laku ini merupakan perwujudan dari kesadaran menjalankan peran, fungsi, dan tugasnya mengemban amanah dan tanggung jawab", sementara tabiat sebaliknya mengindikasikan "sejumlah perangai buruk seseorang". Dalam pembentukan manusia, peran karakter tidak dapat disisihkan, bahkan sesungguhnya karakter inilah yang menempatkan baik atau tidaknya seseorang. Posisi karakter bukan menjadi pendamping kompetensi, melainkan menjadi dasar, ruh, atau jiwanya. Lebih jauh, tanpa karakter, peningkatan diri dari kompetensi dapat menjadi liar, berjalan tanpa rambu dan aturan. Pembangunan karakter bangsa secara real dilakukan dengan membantu siswa berkarakter, sehingga kebanyakan program berintikan penyampaian nilai-nilai karakter bangsa yang diharapkan dapat dimiliki dan dikembangkan oleh siswa di dalam hidup selanjutnya. Oleh Kementerian Pendidikan dan Kebudayaan (Kemdikbud), telah dirumuskan 18 nilai pendidikan budaya dan karakter bangsa yang diharapkan untuk disampaikan kepada siswa dalam pendidikan formal. Nilai-nilai itu adalah: yaitu: (1) religius, (2) jujur, (3) toleransi, (4) disiplin, (5) kerja keras, (6) kreatif, (7) mandiri, (8) demokratis, (9) rasa ingin tahu, (10) semangat kebangsaan, (11) cinta tanah air, (12) menghargai prestasi, (13) bersahabat/ komunikatif, (14) cinta damai, (15) gemar membaca, (16) peduli lingkungan, (17) peduli sosial, (18) tanggung jawab (Syarief ,2017).

Karakter yang berkualitas perlu dibentuk dan dibina sejak usia dini. Usia dini merupakan masa kritis bagi pembentukan karakter seseorang. Banyak pakar mengatakan bahwa kegagalan penanaman karakter sejak usia dini, akan membentuk pribadi yang bermasalah dimasa dewasanya kelak. Selain itu, menanamkan moral kepada generasi muda adalah usaha yang strategis. Oleh karena itu penanaman moral melalui pendidikan karakter sedini mungkin kepada anak-anak adalah kunci utama untuk membangun bangsa. Dalam UU No 20 Tahun 2003 Tentang Sistem Pendidikan Nasional pada Pasal 3, yang menyebutkan bahwa pendidikan nasional berfungsi mengembangkan kemampuan dan membentuk karakter serta peradaban bangsa yang bermartabat dalam rangka mencerdaskan kehidupan bangsa. Pendidikan nasional bertujuan untuk berkembangnya potensi peserta didik agar menjadi manusia yang beriman dan bertakwa kepada Tuhan Yang Maha Esa, berakhlak mulia, sehat, berilmu, cakap, kreatif, mandiri, dan menjadi warga negara yang demokratis serta bertanggung jawab (Cahyono ,2015).

Melalui ekstrakurikuler terutama ekstrakurikuler seni tari diharapkan dapat membentuk nilai karakter terutama nilai karakter bersahabat atau komunikatif terharap siswa SD . Dalam kegiatan ekstrakurikuler seni tari juga banyak mengandung perenungan sehingga siswa lebih peka untuk membedakan sesuatu yang baik maupun buruk, termasuk menerapkan perilaku / karakter yang baik pula. Menurut Kemendiknas (2010: 10) Sikap Bersahabat atau Komunikatif adalah tindakan yang memperlihatkan rasa senang berbicara, bergaul, dan bekerja sama dengan orang lain. Melalui kegiatan ekstrakurikuler seni tari dapat meningkatkan peran aktif siswa.

Peran aktif yang dimiliki siswa dalam mengikuti kegiatan ektrakurikuler seni tari untuk membentuk nilai karakter bersahabat di SD adalah kesediaan siswa dalam mengikuti kegiatan ektrakurikuler dengan baik dan benar serta memberikan respon positif terhadap kegiatan ektarukikuler seni yang di ajarkan.

Berdasarkan uraian diatas dapat disimpulkan bahwa Seni tari merupakan bagian dari seni budaya, yang perlu dilestarikan. Disetiap tarian memiliki makna dan arti yang berbeda. Namun meski demikian, didalam tarian terkandung nilai-nilai moral yang akan membawa peserta didik ikut terjun dalam pembenahan moral atau karakter. Kegiatan ektrakurikuler merupakan kegiatan non akademik yang di lakukan di luar jam pelajaran yang bertujuan untuk menggali bakat dan minat siswa. Siswa tidak hanya perlu pendidikan akademik namun perlu juga memiliki kepribadian yang baik dan karakter yang baik. Dengan adanya kegiatan ekstrakurikuler yang di selenggarakan di sekolah menjadi salah satu cara 
untukmengembangkan berbagai potensi yang dimiliki oleh setiap individu dan memberikan manfaat yang baik bagi siswa yang mengikuti ekstrakurikuler tersebut karena waktu luangnya digunakan untuk hal yang dapat memberikan dampak postif

Kesenian tari melangkah maju dan berkembang sejalan dengan kehidupan manusia. Dimana manusia masih mampu bergerak, maka tari akan tercipta dan berkembang. Manusia menciptakan tari sesuai dengan ungkapan hidup dan juga merupakan rangkuman gerak yang bersumber dari alam se-keliling. Menurut M.Jazuli (2008:7), tari adalah bentuk gerak yang indah, lahir dari tubuh yang bergerak, berirama dan berjiwa sesuai dengan maksud dan tujuan tari. Tari merupakan ekspresi jiwa manusia yang diungkapkan dengan gerak ritmis yang indah (soedarsono, 1986: 24). Tari adalah gerak ritme yang (dengan kesadaran) dibentuk dengan tubuh sebagai media di dalam ruang (Corrie Hartong 1996: 32). Tari adalah salah satu pernyataan budaya. Oleh karena itu maka sifat, gaya dan fungsi tari selalu tak dapat dilepaskan dari kebudayaan yang menghasilkannya (Sedyawati, 1986:3). Hidup dan tumbuhnya tari sangat erat berkaitan dengan citra masing-masing kebudayaan itu, bahwa tari diciptakan dan digiati dalam lingkungan tertentu, sehingga nilai kehadirannya pun tergantung pada lingkungan tersebut. Sekian banyak kekayaan seni budaya Indonesia, tari adalah salah satu bidang seni yang merupakan bagian dari kehidupan manusia. Tari merupakan kegiatan kreatif dan konstruktif yang dapat menimbulkan intensitas emosional dan makna. Menurut Amir rochyatmo (1986:73), tari adalah gerak ritmis yang indah sebagai ekspresi jiwa manusia, dengan memperhatikan unsur ruang dan waktu. Begitupun dengan tari Kridha Jati yang menggambarkan kegiatan masyarakat Jepara terhadap kegiatan mengukir, mempunyai nilai keindahan tersendiri sebagai tari khas kabupaten Jepara yang mengidentitaskan sebagian besar kegiatan masyrakat Jepara. Tari juga bisa dibedakan berdasarkan pola garap. Dimaksudkan dalam penelitian ini adalah tari Kridha Jati yang berdasarkan pola garap, merupakan tari Tradisional. Tari tradisional adalah tari yang lahir, tumbuh, berkembang dalam suatu masyarakat yang kemudian diturunkan atau diwariskan secara terus menerus dari generasi kegenerasi. Dengan kata lain, selama tarian tersebut masih sesuai dan diakui oleh masyarakat pendukungnya termasuk tari tradisional (M.Jazuli, 2008:71). (Khutniah ,2012).

Berdasarkan hasil wawancara yang dilaksanakan pada tanggal 15 November 2018 kepada kepala sekolah SDN Tlogomulyo Semarang Ibu Muntiah, S.Pd mengatakan bahwa dengan menerapkan kegaiatan ekstrakurikuler tari ini yaitu guna melestarikan budaya dan melatih mengembangkan bakat yang dimiliki oleh peserta didik. Kegiatan wawancara yang kedua yaitu dengan pelatih tari yaitu Bapak Suparji, S.Pd mengatakan dengan menerapkan kegiatan ekstrakurikuler tari yaitu untuk mempersiapkan keterampilan menari siswa SD ke pendidikan selanjutnya, mendekatkan anak agar supaya cinta dengan budaya, mengembangkan bakat dan potensi yang dimiliki siswa, menumbuhkan nilai karakter dan sopan santun siswa.

Dengan demikian untuk mengetahui bagaimana peran aktif kegiatan ekstrakurikuler seni tari dalam membentuk nilai karakter bersahabat siswa SDN Tlogomulyo Semarang maka penulis tertarik untuk melakukan penelitian dengan judul "Peran Aktif Kegiatan Ekstrakurikuler Seni Tari Dalam Membentuk Nilai Karakter Bersahabat Siswa SDN Tlogomulyo Semarang".

\section{Metode}

Metode penelitian yang digunakan adalah metode kualitatif. Penelitian kualitatif merupakan metode dengan beraneka segi fokus yang meliputi suatu interpretif, konstruktif, pendekatan naturalistik pada subjeknya (Trumbull \& Watson, 2010). Hal ini bermakna penelitian kualitatif mempelajari sesuatu pada sudut pandang alamiahnya, menerjemahkannya, dan melihat fenomena dalam hal makna yang dipahami manusia. Dengan kata lain penelitian kualitatif dapat mempelajari sisi nyata dunia, menemukan bagaimana orang mengatasi sesuatu dan berkembang dalam situasi tersebut yang menggambarkan kehidupan manusia kontekstual (Yin, 2011, p.6). Denzim \& Lincoln (1994), Patton (2002) menuturkan bahwa penelitian kualitatif meliputi studi yang menggunakan dan mengumpulkan beragam studi kasus bahan empiris, pengalaman pribadi, introspektif, ceritera kehidupan, wawancara, observasional, historikal, interaksional, dan teks visual yang menggambarkan peristiwa rutinitas dan problematis dan makna dari kehidupan individual (Trumbull \& Watson, 2010; p.62) (Azmi ,2018). Pendekatan dilakukan adalah deskripstif kualitatif yang dilakukan dengan menggunakan fakta-fakta atau data-data yang diperoleh dari sumber data. Penelitian menjabarkan tentang peran aktif kegiatan ekstrakurikuler seni tari dalam membentuk nilai karakter bersahabat siswa SDN Tlogomulyo Semarang. Pada penelitian ini teknik pengumpulan data yang digunakan peneliti dalam 
melakukan penelitian ini yaitu observasi, wawancara, angket dan dokumentasi. Penguji keabsahan data pada penelitian ini menggunakan teknik Triangulasi. Untuk pengujian keabsahan data penelitian ini menggunakan triangulasi teknik pengumpulan data yaitu wawancara, observasi dan angket. Sedangkan analisis data pada penelitian ini menggunakan reduksi data, penyajian data, dan verification.

\section{Hasil dan Pembahasan}

Proses kegiatan ekstrakurikuler seni tari di SDN Tlogomulyo dilaksanakan setiap hari kamis pukul 15.30 sampe 17.00 WIB. Kegiatan ekstrakurikuler dilaksanakan di luar atau di halaman sekolah yang luas karena di SDN Tlogomulyo Semarang belum memiliki aula. Guru pelatih mengajarkan tarian kepada siswa dengan sungguh - sungguh dan dilakukan berulang ulang kali sampai siswa paham dan bisa menirukan gerakan tari. Sebelum proses ektrakurikuler biasayanga siswa dan guru pelatih berdoa dan bersiap siap terlebih dahulu. Dari pengamatan peneliti ekstrakurikuler dilakukan setiap minggunya.

Sarana dan prasarana ekstrakurikuler seni tari di SDN Tlogomulyo kurang memenuhi standar. Hal ini dapat diketahui ketika observasi property tari yang digunakan hanya instrument musik saja dan tidak ada property yang lain. Tempat yang digunakan dalam kegiatan ekstrakurikuler seni tari juga belum memenuhi standar. Hal ini dapat diketahui ketika kegiatan ekstrakurikuler seni tari dilakukan di halaman sekolah, dan ketika hujan ekstrakurikuler tidak berjalan dengan baik karena tidak mempunyai aula tersendiri untuk kegiatan.

Berdasarkan hasil wawancara dengan Ibu kepala sekolah yang bernama lbu Muntiah, S,Pd bahwa ektrakurikuler seni tari sudah ada sebelum beliau menjadi Kepa Sekolah di SDN Tlogomulyo Semarang. Kegiatan ekstrakurikuler seni tari berpengaruh terhadap pendidikan nilai karakter khususnya nilai karakter bersahabat karean dengan adanya seni tari akan tertatt sikap sikap anak yang toleran sesama temannya, saling tolong menolong, dapat menumbuhkan rasa rela berkorban, dan bekerja sama.

Berdasarkan dari wawancara dengan guru pelatih, kegiatan ekstrakurikuler seni tari sangat membantu karakter terutama karakter bersahabat siswa untuk mengasah ketrampilan dan budi pekerti. Berdasarkan angket yang telah peneliti lakukan, angekt terdiri dari 20 pernyataan yang harus diisi oleh siswa dengan cara memberi tanda centang $(\sqrt{ })$ pada salah satualternatif jawaban. Setiap nomor terdapat empat alternatife jawaban yaitu selalu, sering, kadang - kadang, dan tidak pernah. Skor masing masing alternatife jawaban yaitu, selalu 4 skor, sering 3skor, kadang -kadang 2 skor, dan tidak pernah 1 skor. Siswa yang mengikuti ekstrakurikuler seni tari di SDN Tlogomulyo Semarang sebanyak 25 siswa. Hasil angket dari 25 siswa.

Berdasarkan hasil penemuan observasi yang dilakukan oleh peneliti bahwa peran aktif kegiatan ekstrakurikuler dalam membentuk nilai karakter bersahabat siswa sudah terlaksana dengan baik, siswa yang mengikuti ekstrakurikuler seni tari sudah bisa bekerjasama dengan temannya, siswa mengenal semua temannya yang mengikuti ekstrakurikuler seni tari, siswa dengan teman temannya dapat berkomunikasi dengan baik, siswa tidak jaga jarak dengan teman temannya. Dalam hal tersebut nilai karakter khususnya nilai karakter bershabat yang ada di ekstrakurikuler seni tari sudah tumbuh dengan baik.

\section{Simpulan dan Saran}

Dari hasil penelitian yang telah dilaksanakan dengan judul Peran Aktif Kegiatan Ekstrakurikuler Seni Tari Dalam Membentuk Nilai Karakter Bersahabat Siswa SDN Tlogomulyo Semarang, dapat disimpulkan bahwa kegiatan ekstrakurikuler seni tari membentuk nilai karakter bersahabat, karena dalam proses ekstrakurikuler seni tari siswa tolong menolong terhadap temannya, siswa dengan teman - temannya juga berkomunikasi dengan baik, siswa mengenal semua temannya yang ikut menari. Hal ini dapat dibuktikan dari observasi, karena dalam observasi siswa saling tolong menolong, jika tari berkelompok siswa kompak dalam menarikannya.

Peneliti ini hanya membatasi permasalahan yang memfokuskan pada ekstrakurikuler seni tari saja, naaun dalam hal ini peneliti lebih menitikberatkan dalam membentuk nilai karakter bersahabat. Isi data penelitian yang peneliti dapatkan masih banyak kekurangan dan peneliti menyadai bahwa penelitian ini belum sempurna, karena keterbatasan pengetahuan serta keterbatasan dana, waktu, dan tenaga 
IVCEJ, Vol 2 No 1, Tahun 2019

p-ISSN: 2615-4684 e-ISSN: 2615-6938

\section{Daftar Pustaka}

Arikunto, Suharsimi. (2010). Prosedur Penelitian Suatu Pendekatan Praktik. Jakarta: Rineka Cipta.

Assidiqi , Hasby (2015). Membentuk Karakter Peserta Didik Melalui Model Pembelajaran Search, Solve, Create, And Share . Jurnal Pendidikan Matematika Vol. 1, No.1, Januari April 2015 @ STKIP PGRI Banjarmasin

Azmi ,Zul (2018). Memahami Penelitian Kualitatif Dalam Akuntansi . Jurnal Ilmu Akuntansi Volume 11 (1), 2018: 159 - 168 P-ISSN: 1979-858X; E-ISSN: 2461-1190

Azzet, Akhmad Muhaimin. (2011). Urgensi Pendidikan Karakter di Indonesia. Jogjakarta: ARRUZZ MEDIA.

Cahyono ,Hadi (2015). POLA PENGEMBANGAN PENDIDIKAN KARAKTER SISWA (Sebuah Studi Di SDN 1 Polorejo) . Jurnal Dimensi Pendidikan dan Pembelajaran Vol. 3 No. 2 Juli 2015

Dra. Fuji Astuti, M. (2016). Pengetahuan dan Teknik Menata Tari Untuk Anak Usia Dini. Padang: Kencana.

Khutniah ,Nainul (2012). Upaya Mempertahankan Eksistensi Tari Kridha Jati Di Sanggar Hayu Budaya Kelurahan Pengkol Jepara . Jurnal Seni Tari JST 1 (1) (2012)

Lestari, Y. S. (2016). Implementasi Pendidikan Karakter Melalui Kegiatan Ekstrakurikuler Seni Tari Di Sekolah Dasar Negeri 1 Trirenggo Tahun Pelajaran 2015/2016. Trihayu : Jurnal Pendidikan ke-SD-an, Vol. 3, No 1, September 2016, hlm. 38-42, 40-41.

Moleong Lexy J. (2017). Metodelogi Penelitian Kualitatif. Bandung: Remaja Rosdakarya

Noor Yanti, R. A. (2016). Pelaksaaan Kegiatan Ekstrakurikuler Dalam Rangka Pengembangan Nilai-Nilai Karakter Siswa Untuk Menjadi Warga Negara Yang Baik Di SMA Kopri Banjarmasin. Jurnal Pendidikan Kewarganegaraan: Volume 6, Nomor 11, Mei 2016, 964.

Noor Yanti, R. A. (2016). Pelaksanaan kegiatan ekstrakurikuler dalam rangka pengembangan nilai nilai karakter siswa untuk menjadi warga negara yang baik di SMA KORPRI Banjarmasin. Jurnal Pendidikan Kewarganegaraan: Volume 6, Nomor 11, mei 2016, 965.

Nurkholis (2013). Pendidikan Dalam Upaya Memajukan Teknologi . Jurnal Kependidikan, Vol. 1 No. 1 Nopember 2013

Novi Mulyani, M. (2016). Pendidikan Seni Tari Anak Usia Dini. Cilacap: GAVA MEDIA.

Samani Muchlas \& Hariyanto (2013). Konsep dan Model Pendidikan Karakter. Bandung: REMAJA ROSDAKARYA.

Sari, P. I. (2017). Eksplorasi Minat Belajar Siswa Dalam Mata Pelajaran Seni Tari Di SD Taman Muda Ibu Pawiyatan Yogyakarta. SOSIOHUMANIORA- Vol 3, No 1, April 2017 - Jurnal LP3M-Universitas Sarjanawiyata Tamansari Yogyakarta, 51.

Sustiawati ,Luh (Pengembangan Desain Pembelajaran Seni Tari Di Sekolah Dasar Berbasis Localgenius Knowledge Berpendekatan Integrated Learning . Jurnal Seni Budaya Volume 32, Nomor 1, Mei 2017 
IVCEJ, Vol 2 No 1, Tahun 2019

p-ISSN: 2615-4684 e-ISSN: 2615-6938

Suyito ,Imam (2012). Pengembangan Pendidikan Karakter Dan Budaya Bangsa Berwawasan Kearifan Lokal . Jurnal Pendidikan Karakter, Tahun II, Nomor 1, Februari 2012

Syarief, Hasnan (2017). Implementasi Pendidikan Karakter Siswa Perguruan Islam An-Nizam Medan . Jurnal EduTech Vol. 3 No. 1 Maret 2017 ISSN: 2442-6024 e-ISSN: 2442-7063

Yuni ,Ria (2016). Peran Kegiatan Ekstrakurikuler Dalam Mengembangkan Watak Kewarganegaraan Peserta Didik .Jurnal UCEJ, Vol. 1, No. 2, Desember 2016 